Girls, gender and intersecting inequalities in education: A reflection from case studies in South Africa and Kenya ${ }^{1}$

Elaine Unterhalter (Institute of Education, University of London), Jenni Karlsson (University of KwaZulu Natal), Amy North (Institute of Education, University of London), Chris Yates (Institute of Education, University of London), Veerle Dieltiens (University of the Witwatersrand), Setungoane Letsatsi (University of the Witwatersrand), Herbert Makinda (Catholic University of Eastern Africa), Jane Onsongo (Catholic University of Eastern Africa).

In assessing achievements worldwide in expanding access to schooling for girls, it is evident large challenges remain in relation to inequalities associated with gender, poverty, location, racial or ethnic divisions and disability. The first part of the paper discusses the ways in which gender, girls and education have been written about in some key works on poverty. It raises questions about how poverty, gender and schooling are defined and suggests the concept of intersectionality, may be useful in considering the ways in which inequalities form and are formed by each other.

The second part of the paper considers some effects of viewing the relationship of poverty, gender and schooling in static and stereotyped terms. It reports on data gathered regarding engagements with global and national government policy on gender, education and poverty in Kenya and South Africa. In both countries, there has been a government focus on education and poverty with some attention to gender issues, but considering the intersections remains a challenge.

\title{
Gender, education and poverty
}

UNESCO's (2010) most recent Global Monitoring Report brings out graphically how gender marks the experience of poverty and limits possibilities of entering into and flourishing at school. Mothers' illhealth, associated with hunger and lack of adequate antenatal care, means that even before many children are born they are deprived. From birth they do not have the nutrients they need to grow up well, and the poor health of mothers, which might lead to sickness and early death, could blight childhoods and the capacity to learn (UNESCO, 2010, 45-48).

\footnotetext{
${ }^{1}$ This paper draws on research conducted as part of the project Gender, education and global poverty reduction funded by the UK Economic and Social Research Council (ESRC) Award no. RES 167-25-260
} 
While numbers of out of school children have declined, and the share of girls in the out of school population has come down from 58\% in 1999 to $54 \%$ in 2010, in some countries there has been only limited progress in getting children into school and girls, primarily girls from the poorest households, remain one of the groups most at risk of never attending school. For example, in Pakistan, in 2006 girls accounted for $60 \%$ of the children out of school; being a girl from a rural area in one of Cambodia's hill provinces increased the chance of not attending school by a factor of five, while in Nigeria only $12 \%$ of poor Hausa girls from rural areas attend school (UNESCO, 2010, 58; 152). The odds on getting to school are heavily stacked against girls from poor, generally rural households. This is shown graphically in data from 14 countries which each had more than 500,000 children out of school in 2007; in twelve countries girls out of school were less likely than boys to get into school (UNESCO, 2010, 65). In Yemen rural girls' enrolment is dramatically lower than boys' in the lowest quintile (UNESCO, 2010,67) and there is a similar picture to be seen in Pakistan when attendance is analysed (UNESCO, 2010,68). In a number of countries girls in the poorest households are much more likely to have less than four years schooling than boys from the same households (UNESCO, $2010,140-141)$. A review of household data in countries which made the biggest gains in expanding net enrolment ratios and overcoming gender gaps in the last decade, shows that the increases in enrolment were largely in the richest, not the poorest, quintiles (Unterhalter, 2010). The consequences are evident in a number of countries surveyed for the UNESCO Global Monitoring Report, which show female youth unemployment is higher than males (UNESCO, 2010, 83), and how geographic and socio-economic divisions are a key component of the gender division in illiteracy (UNESCO, 2010, 101).

The figures give a graphic sense of the scale of gender gaps and disparities based on region and wealth. But what helps explain the gender dynamics of what the UNESCO report calls education poverty? The report draws on analyses of income poverty such as US $\$ 1.25$ a day to suggest that 'education poverty' or 'extreme education poverty' can be understood as 'bottom lines' of four or two year thresholds in school (UNESCO, 2010, 139). It shows how being rural or in some cases from a particular ethnic group or region, or coming from an area with a history of conflict, all exacerbate the chance of falling below the line of education poverty and that being a girl always means one is further below the line than a boy from the same community (UNESCO, 2010, 139-154).

The literature on gender, education and social division does not take quite such a static approach to education poverty. A number of studies point to the complex juggling poor families engage in when deciding whether to invest scarce resources in the schooling of girls and boys. Fleisch and Shindler's (2009) analysis of birth cohort data over a primary school cycle in South Africa suggests boys are 
more likely than girls to repeat a grade, possibly improving attainment. We do not have the qualitative data which would explain whether these data reflect decisions of parents or schools, but the pattern suggests gender is a variable in decisions about progression. Analyses of a number of societies that engage in nomadic pastoralism note that girls are kept out of schools more than boys, but that there are complex economic, generational and symbolic calculations and strategies at play (Leggett, 2005; Lesorogol, 2009). In countries with very poor and remote communities and prominent ethnic and caste divisions, gender gaps in education are particularly prominent but are as much associated with intra-community relationships involved with culture or religion, practices of bonded labour, and the fine-grained relationships of age and marriage which a 'blunt' definition of education poverty as a set number of years in school does not capture (Maslak, 2002; Giri, 2009; Sen, Rastogi and Vanneman, 2006).

Particular features of location and poverty, as well as family dynamics, bear on the question of whether girls or boys go to and stay at school. Gender gaps are also noted in large slum communities that have grown up with very rapid urbanisation, and it is suggested for slums in Kenya (Mugisha, 2006) and Mumbai (Kumar, Kumar and Anurag, 2007) the advantage of living in an urban area may not be sustained for slum children, particularly girls. Huisman and Smits (2009), in a cross country analysis of district level data,draw out that decisions to keep children in school are related to parents assessments of the quality of schooling, but also the extent of white collar employment in the area and the position of women relative to men.

The ways in which the formal economy operates and levels of social protection also have particular consequences for decisions about which children go to school. The large literature on gender and the care economy identifies the ways in which the burden of care for young children, the old and the sick falls disproportionately on women (e.g. Chant,2007, 2008; Kabeer, 1996, 2008). This provides some insight into the household sexual division of labour which inhibits girls' full participation in schooling.

Government policies on inclusive education and provision for children with disability will also have particular consequences with regard to the poorest communities. Although there are only a handful of studies on gender, disability and access to schooling, it is clear too that disability and poverty are associated with children kept out of school and that here too gender amplifies already discriminatory practice (Emmett, 2006; Filmer, 2008). 
Thus it is evident that there are exogenous and endogenous processes at play in poor communities connecting gender, lack of education and poverty. Policy in a wide range of social development areas from economic planning, to housing, agricultural extension or rights for the disabled all help shape the decisions that poor families make about which children go to school. Thus a 'simple' notion of education poverty as a line equivalent to $\$ 1$ a day may not fully capture all these dimensions as it suggests that the mere provision of sufficient education should itself be an inducement for children to enrol, when this is clearly not the case.

Lewis and Lockheed (2006) noted that gender divisions with regard to children out of school were marked in minority groups or communities where ethnic identity was a prominent aspect of social relations. They develop a notion of social exclusion to explain this, drawing out how in some societies poverty is not only associated with lack of economic wellbeing, but with disparagement and marginalisation of the poor by the wealthy. This contributes to limited opportunities, mobility and in some cases an acceptance of these hierarchies by the poor (Lewis and Lockheed, 2008, 10). Their analysis, which rests largely on an interpretation of patterns of enrolment disaggregated by gender and ethnicity, is corroborated by a number of qualitative studies and national overviews. These indicate how, in societies marked by deeply entrenched social division on grounds of race, ethnicity or caste, gender exacerbates forms of exclusion in complex ways. For example, Ames (2005) and Aikman (1999; 2002), drawing on qualitative studies of indigenous populations in Peru, one in the Andes and one in the Amazon, both draw out the complex processes entailed in affirming indigenous identity, maintaining household economies and a particular sexual and generational division of labour under conditions of hardship, and how this often forces an impossible choice between subsistence or sending girls to school. Ramachandran (2001) and Bandyopadhyay and Subrahmanian (2008), in surveying Indian trends in enrolment and progression over decades, note how in certain states there are marked gender gaps in progression to upper levels of elementary school for scheduled caste and scheduled tribe girls. Expansion of provision in lower grades often takes the form of informal or bridge schools close to habitations, which raise serious concerns about equality and integration within the wider education system. Morrell et al (2009), using qualitative data collected in a number of different schools in South Africa, draw out how the history of racial division and poverty has a bearing on the ways in which teachers convey information about gender equality and the threat of HIV. All these studies suggest that the forms of social exclusion associated with ethnicity, poverty or race are multi-faceted and require policy and practice responses that acknowledge this. 
The idea of education poverty levels or poverty and social exclusion are to be welcomed because they draw attention to some connections between gender, poverty and schooling. But both these conceptions of the problem of poverty have features that make them appear too static. The idea of education poverty levels suggests that once the line of two or four years of schooling has been crossed, there is less need for policy concern regarding gender equality and education, which is clearly not the case. Gender inequalities persist in school and as a consequence of schooling and attaining sufficient schooling to cross a line of education poverty is no guarantee for an individual or a society that conditions for gender equality are being established (Unterhalter, 2007; Aikman and Unterhalter, 2005; Maslak, 2008). The idea of social exclusion suggests that certain barriers to full participation in a society are put in place by the rich or the poor. These work to mark boundaries of exclusion. This implies poverty and girls' withdrawal from schooling are a result of forms of identification made in response to these barriers. Hence they are not the outcome of any distributional problems or forms of social segregation. The implied policy response signals less racial or ethnic belonging would be better for girls' education. This is problematic on a number of grounds. Firstly, because some groups come to be defined entirely by ethnicity, when much of the research literature shows that ethnicity or race might be quite mutable in different settings, and that location, age, family composition, social relations in the neighbourhood may be just as relevant aspects of a group or individual's actions or decisions about which children go to or stay in school. Secondly, this approach suggests ethnicity for poor communities extinguishes educational aspiration for girls, rather than providing a resource for it. This is clearly not the case everywhere in the world. Moreover the analysis gives no attention to the historical context which might have shaped these outcomes and which needs to be an important component of any response. Thirdly, this policy 'take' fails to understand sufficiently why poor ethnicised or racialised communities might comply with the exclusion of their children from schooling.

To overcome some of these static ways of thinking about poverty, gender and schooling, and seeing ideas that can capture the multidimensionality of these relationships, we have been particularly interested in sociological work on intersectionality. The term intersectionality was coined by Kimberlé Crenshaw in 1989 (Crenshaw, 1989), although even before that date many feminist scholars noted how women's subordination entailed aspects of race, gender and class division, all of which involved relational dynamics that were economic, political, social and cultural (e.g. hooks 1981, 1992, 1994; Nnaemeka 2004; Anthias and Yuval-Davis 1983; Skeggs 1997). However, debates about interesectionality abound. One group of commentators question whether the notion implies that all forms of social division are roughly equivalent and whether it over-emphasises structures of subordination (Phoenix and Pattynama, 2006; Brah and Phoenix, 2004; Valentine, 2007). Others 
consider how ideas about complexity and their methodological challenges can help deepen understanding about how intersectionality works (McDowell, 2008). Engaging that debate is beyond the scope of this paper, but we consider that the concept of intersectionality provides intellectual resources to examine that different forms of social division, associated identities and the ways in which these have been formed and informed by each other. Intersectionality has been interestingly used in looking at how social policy responds to gender mainstreaming approaches (Verloo, 2006) and thus it seems to offer some promising ways to go beyond the static configurations of poverty lines or identities in some of the literature discussed above.

Drawing on aspects of the concept of intersectionality, we consider it is important to go beyond descriptive outlines of the way poverty, gender and lack of schooling are associated with each other. In thinking about questions of gender, education and poverty, we draw on Unterhalter's (2009) three metaphors for analysing these to understand the different relationships at play. This work distinguishes between three meanings of poverty: as a line, a net and as fuel, and links these with different ways of thinking about gender and implicitly about understanding what is to be done regarding girls' schooling. Her analysis calls for the importance of understanding the intersectionality of different dynamics of poverty, gender and schooling, and draws out the importance of attending both to what works to include the poorest girls in schooling, and to the values they express about what matters to them both in school and beyond.

In thinking about poverty as a line, one can count the numbers of women and men above or below a poverty line, whether or not this is understood in terms of income or consumption. The UNESCO GMR draws directly on the notion of poverty as a line in understanding education poverty as those who are above or below a distributional level of two or four years at school. Clearly this idea about poverty works with an understanding of what Unterhalter (2007) has called gender as a noun, thus a descriptive identification of numbers of girls and boys in or out of school or achieving particular grades or levels of employment.

Unterhalter (2009) contrasts this notion of poverty as a line with a different notion of poverty as structural, a net, in which the economic relations of survival, including the sexual division of labour in the household, mean that it is difficult to transform gender relationships which are enmeshed with particular relations of production concerning the kinds of work that are available for women and men. In this analysis gender is understood as a feature of household, community and national power relationships. Unterhalter (2007) refers to this approach as seeing gender as an adjective, an attribute of the relationships of power which form structures of inequality. Hence gendered relationships in schools articulate with wider relationships in both meanings of the term. The 
boundaries and networks that discursively form the net of poverty (and speak /articulate it) are as much constituted by coercive economic and political relations as of inequality maintained over generations associated with divisions of race, ethnicity, caste or location (which all connect up/articulate).

Schools reproduce and express gendered assumptions about what is suitable learning or behaviour for girls and boys. For example, detailed studies of poor girls' views give us accounts of teachers and girls themselves who believe they are not capable of succeeding at science or maths (Raynor 2007; Morley and Lugg 2009; Kamwendo, 2010). A number of studies show how it is taken for granted at school that boys cannot do cleaning because this is not culturally appropriate (Leach and Humphreys, 2007; Lloyd, Grant and Ritchie, 2008; Hsin, 2007). However, in carrying out cleaning, girls, particularly girls from the poorest communities, come to accept cultural scripts about subordination. Other studies show that although boys in the poorest schools may appear, 'naughty' and demanding of teachers' attention at school, this builds a strong sense of identity, which can be valuable in supporting confident self assertion, which are denied to girls who quietly 'get on' with completing the lessons set (Page, 2005; Bhana and Epstein, 2007).

Schools play a particular role in poor families strategies for economic or cultural survival. Households might calculate men need to migrate because they can find work in commercial agriculture or cities, while women need to remain at home to keep the household access to land or livestock. As a result girls might be kept out of school, possibly because it is too expensive or because they are needed to attend to household chores, while older women look after fields, marketing or household maintenance. The investment in the household survival, through this sexual division of labour, may be a much more pressing reality than sending girls to school (Ames, 2005; Aarends Kuenning and Amin, 2007). In these conditions it might be very hard for poor parents to effect change in educational conditions so that schools are more responsive to their needs. Indeed in some countries where enrolment campaigns have been vigorously pursued, a head of a poor household might be punished by a local chief for not sending girls to school. The establishment of 'informal 'schools closer to habitations have been successful in India and Bagladesh in increasing attendance by poor girls (Aarends Kuenning \& Amin; Bandyopadhyay, and Subrahmanian, (2008) but this does not fully address the question of what happens when girls have to travel longer distances to attend higher grades. While forms of social grant or conditional cash transfers might ease some of the economic pressures regarding why girls do not attend school (Fiszbein and Schady 2009), they cannot fully address the questions relating to the sexual division of labour in the household and the precariousness of short-term planning by poor households. This is why the less these grants are conditional and the more schooling is accessible and affordable, the better the take up is (Molyneux 2006). 
In this analysis the social division associated with poverty as a net is marked by a racialised, ethnicised or status marked boundary which imposes particular economic, social, political and cultural relationships on poor households. Women and girls are often associated with marking the boundary because of their dress, concerns about who they marry and at what age. Thus what is noted comes to be, for example, ethnic identity and girls who are taken out of school, rather than a more nuanced appreciation of how ethnicity, gender and the relations of poverty might make it difficult to escape from the network of relationships in which gender, ethnicity and poverty all intersect.

The third meaning Unterhalter (2009) provides for poverty is as a fuel using two meanings of the word fuel. Fuel is what can propel you forward, energise, and result in an activism that can move an individual or a community out of poverty. But a fuel, such as petrol, is also a toxin. Some forms of identification evident in studies of the 'voices of the poor' are associated with adaptive preference, and satisfaction with very little education. Some studies report that poor women think that because they are poor they are stupid (Oommen, 2005; Shin, 2008; Deprez, 2007). These forms of enactment of poverty, just like crime and violence as the forms of survival, are often toxic for the poor. Anger at a certain ascribed gender identity could propel a community or groups or girls or boys out of poverty, but it could also take the form of 'acting out' dangerous gender identities associated with masculinity and femininity ( Parkes 2007; Swartz and Bhana, 2009; Greany 2010). Unterhalter (2007) has referred these processes as entailing 'gender as a verb'. It may be that girls and boys repeatedly act and consolidate particular gender identities at school, either because they are trying to use school as a platform to get out from particular identities and relationships, to cross the borders or cut the mesh of the net, or because they accept that schools are 'good enough' because they are poor and hence 'deserve' no better.

Ruth Lister (2004) has written about poverty as a hub and it seems this notion offers an insight into the ways in which poverty intersects with many forms of gendered social structures and actions. Gender forms and is formed by different processes where poverty presents line of income or consumption, nets of difficult or rewarding relationships and fuels to drive or undermine change. Schooling may work to reinforce exclusions and mark the lines and network of relationships dictating who can pay or adapt to particular school gender regimes and whether the fuel of action it provides is nourishing or destructive. But schooling can also contribute to building the relationships of support that sustain poor communities and provide the fuel to transform gendered relationships of poverty. In From Poverty to Power, Green (2008), argues for a multidimensional understanding of poverty that goes beyond incomes to consider the sense "of powerlessness, frustration, exhaustion, 
and exclusion from decision-making" experienced by people living in poverty, as well as their lack of access to public services and the financial system (Green 2008, p7). Poverty is thus seen as a "symptom of deeply rooted inequities and unequal power relationships, institutionalised through policies and practices at the levels of state, society, and household" (Green p 27). Gender - as well as class, ethnicity, sexuality and age - is identified as one aspect of individuals' personal identity that is linked to discrimination at different levels, and which can constrain the ability of individuals to access and control resources and services - including education - and make decisions about their lives. Green argues that overcoming poverty - and achieving "wellbeing" - requires both "active citizens" who are "able to determine the course of their own lives, fighting for rights and justice in their own societies" and "effective states" that can deliver essential services and manage the process of economic growth. This suggests paying attention to both poverty as fuel and poverty as a net. Green's analysis mentions close links between gender inequalities, education, and dimensions of poverty, seeing gender inequalities as constraining girls' and women's realisation of the right to education, as well as viewing the education of women and girls as important in challenging inequities. However, there is little deeper analysis of the sort of education required to do this, or the way in which multiple forms of exclusion play out within the school space.

In the next section of the paper we draw on data collected from 2008 in South Africa and Kenya looking at engagement with poverty, education and gender in six sites: the national Department/Ministry of Education, a provincial department, a school and an NGO operating in the capital city and a rural location (For additional papers reporting on data from this project see Unterhalter et al, 2009; Dieltiens et al, 2009; Karlsson, 2010 forthcoming; North, 2010, forthcoming; Onsongo et al, 2009). Through discussion of selected data from this project we review how different levels of government, school communities and NGO workers have engaged with the question of the hub of poverty and the intersecting inequalities implicated in these relationships.

\section{The politics of poverty, gender and schooling}

South Africa and Kenya are both countries marked by large inequalities associated with wealth, location, and race. In both, governments have paid attention to poverty and gender issues in education. 


\section{South Africa}

During South Africa's years of apartheid rule (1948-1994) a race-based system of social division consolidated and deepened other inequalities. In 1994 the Constitutional democracy introduced the African National Congress's policy framework for broad social transformation: the Reconstruction and Development Programme (RDP) (African National Congress 1994; Ministry in the Office of the President 1994). The RDP sought to redistribute power, resources and opportunities and thereby transform the economic system, which was predicated on racially-differentiated education and training systems and a biased labour market system (Marais 1998). Accompanying the RDP were welfarist national initiatives that included the school nutrition programme providing meals to school children in dire poverty conditions, and free health care for pregnant women and young children. The conditions in 1994 which the RDP was designed to address are described by Hein Marais (1998, 106-7):

South Africa's Gini coefficient is 0,68 , worse that that of the Bahamas, Brazil or Jamaica (and 33 other developing countries). [...] Africans living in rural areas constitute 70 per cent of South Africa's poor, with the majority of those households headed by or containing only women. In those areas, only 7 per cent of households have access to flush toilets, 11 per cent to electricity, 5 per cent to garbage collection. [...] Inequality is most fiercely visited upon women, preponderantly African women and especially in rural areas. The most horrifying index of violence is against women, most commonly in the form of battery and sexual abuse.

However, the first post-apartheid government faced considerable pressure internally and externally to make economic adjustments with an eye to attracting investors and competing in the global market. In 1998 the Growth, Employment and Redistribution (GEAR) Plan was introduced, which many argued sidelined the RDP ( Marais 1998; Motala and Pampallis 2007; Seekings and Nattrass 2006). Economic growth associated with an elite, urban Black middleclass was fostered at the expense of redress of historic inequalities and development for the impoverished and weakest quarters of the society.

The tensions this evoked crystalised around the question of how to address development, economic growth and inequality. This played out as a power struggle that eventually saw the resignation of the President following the ruling party's National Conference in December 2007. The Polokwane Resolutions declared renewed commitment to prioritise service delivery at the local level, respond to the acute social needs of the poor and landless especially in rural areas, and issues affecting women, and to reaffirm democratic values, accountability and good governance and pursue 
obligations such as the Millennium Development Goals (African National Congress 2007). However, the subsequent election campaign in 2009 , was characterised partly by these concerns but also by a discourse that emphasised ethnicity and cultural identity, weapons of war, homophobia and intolerance of the rights of girls and women. This drew criticism from some gender activists (Govender 2009). Several changes aligned to the Polokwane Resolutions were introduced by government in 2009, including the appointment of a Cabinet Minister for Women, Children and Persons with Disabilities and the establishment of a Parliamentary Portfolio Committee to oversee its work (van der Westhuizen 2009).

Sixteen years of democracy have seen many initiatives to address gender and poverty. Doors to education, rights and life opportunities for girls have opened. Schooling to the end of Grade 9 is compulsory (Republic of South Africa 1996b). Official statistics indicate that most girls of schoolgoing age are enrolled at and attending school so that $98 \%$ will complete the primary school cycle by 2015. Since 2002 the gender parity index has been 1.00 (Department of Education 2009, 5-17). Several strategies address poverty conditions that hinder girls at school. A School Nutrition Programme providing one free meal a day to children mostly in rural school was an early initiative of President Mandela in 1994, has now been extended to all primary schools which serve the two lowest economic quintiles. In 2010 it encompassed secondary schools in the same categories. Over 9 million poor children were recipients of a small Child Support Grant in 2008/9 and in 2009 this was extended to include 15 year olds (Savides 2009). The grant is used to cover shelter, clothing, food and personal needs. Up to the age of six, poor girls receive free health care from state clinics and hospitals (Lund 2008). In 1997 A Gender Equality Task Team (GETT) reported. As a result the national and provincial education departments established desks with a brief to mainstream gender (Wolpe, Martinez, Quinlan, 1997; Chisholm and September, 2005; Karlsson, 2010 forthcoming). A school curriculum for Life Orientation dealing with gender relations, sexuality and health has been developed (Department of Education 2007). In a number of provinces girls' and boys' clubs have been formed to reflect on gender inequalities, HIV and AIDS. Considerable attention has been given to the development of new textbooks and learning materials. Policy directives are in place so that girls who become pregnant cannot legally be excluded from school.

But for all these achievements, many challenges remain. Unemployment and underemployment remain high, inequalities between the richest and poorest have not decreased, and in 2009 the gini coefficient, after some fall in earlier years, was estimated at between 0.666 and 0.679 (Pressley, 2009). Poverty and inadequate schooling continue to evoke concern and debate. In this, there are many similarities with Kenya where a reform agenda has been even more difficult to effect. 


\section{Kenya}

The National Alliance Rainbow Coalition (NARC) government, led by President Mwai Kibaki was elected in December 2002, and seen by many commentators as an embryonic democracy (Murunga and Nsong'o 2007 ; Murunga 2010 forthcoming ). The latter period of the Moi government (up to 2002) was associated with national indebtedness and the introduction of structural adjustment measures which had a catastrophic effect on education. The primary gross enrollment ratio (GER) which had reached 105\% in the 1989 had declined to around 76\% by 1999 (World Bank, 2003: 3; DFID 1999:2). This was a stark contrast with the goals of the 1990 Jomtien Education for All programme (Yates, Foster and Barasa 2010 forthcoming). Wealth had become strongly concentrated and inequitably distributed. The gini coeffient in 1999, calculated on the basis of household income stood at 0.57 and at 0.625 calculated on a per capita basis (SID 2004). There is a high concentration of income held by the highest earners - 10 percent of the population control 35 percent of the national income. In 2004 a study showed the top 10 percent of households to be controlling $42 \%$ of the total income while the bottom $10 \%$ controlled less than $1 \%$. There were staggering differences in life expectancy with people in Central Province living on average 19 years longer than people in Nyanza. Income and wealth are overwhelming owned by men. It is estimated that only $3 \%$ of women own land (Republic of Kenya 2009:23).

NARC had campaigned on a commitment to improve welfare, promising to introduce Free Primary Education (FPE) and affordable health care. Free Primary Education (FPE) was introduced in January 2003, and Free Secondary Education (FSE) in 2008 with commitments to affordable health provision. The international development community stepped up its assistance to education and health. A US\$50m grant was made by the World Bank to support Free Primary Education (World Bank, 2003) and commitments came from UK DFID, Canadian CIDA and Swedish SIDA to introduce and sustain a national system of free textbooks and other instructional materials. In 2005 the Kenya Education Sector Support Programme (KESSP) was set up assisted by three large education aid payments through the Catalytic Fund of the Fast Track Initiative (FTI) totalling an additional US\$120m. The substantial financial commitment made by multi-lateral and bilateral development agencies to the new government signaled an expectation of a new period of improved transparent governance and more democratic politics and the government was accorded more control over external development finance and its deployment (Thomson et al, 2009). It should be stressed, however, that this substantial external development partner assistance to education never exceeded more than $4 \%$ of the total education budget. The vast majority of the costs needed for this inherently pro-poor education programme were met by the Kenya taxpayer. 
The government prepared a National Poverty Eradication Plan (NPEP) in 1999 and a Poverty Reduction Strategy Paper (PRSP) in 2001-2004 The government's economic development strategy was in theory, based on twin principles of 'democracy and empowerment of the people' outlined in the Economic Strategy for Wealth and Employment Creation 2003-2007 (or Economic Recovery Strategy for short - ERS). The ERS was replaced by Vision 2030 in 2008 which set out goals for Kenya to become a middle income, prosperous country by 2030 . The Vision is distinctly silent on any commitment to improved wealth distribution and better income equality.

FPE succeeded in reversing falling enrollments. Primary enrolments rose from 5.9 to 7.1 million at the start of the new year in January 2003. The implementation of the first KESSP (2005-2010) further extended and consolidated these gains, with primary enrolments continuing to rise to around $8.2 \mathrm{~m}$ by 2008 . The net enrolment ratio (NER) also increased from $80.4 \%$ in 2003 to $86.5 \%$ in 2008. Primary transition rate to secondary education under the Free Secondary Education policy increased from $45.8 \%$ in 2003 to $61.5 \%$ in 2008 (MOE, 2008 provisional statistics). But the gender parity figures in Table 1.1 show these gains were not evenly distributed with gender gaps persisting in Coast and North Eastern Province, and some provinces registering falls in gender parity levels despite FPE.

Table : 1.1 Primary GPI by Province, 2003- 2007

\begin{tabular}{|l|l|l|l|l|l|}
\hline Province & $\mathbf{2 0 0 3}$ & $\mathbf{2 0 0 4}$ & $\mathbf{2 0 0 5}$ & $\mathbf{2 0 0 6}$ & $\mathbf{2 0 0 7}$ \\
\hline Coast & 0.9 & 0.93 & 0.98 & 0.98 & 0.91 \\
\hline Central & 1.01 & 1 & 0.99 & 1 & 0.96 \\
\hline Eastern & 1 & 1 & 0.99 & 0.99 & 0.99 \\
\hline Nairobi & 1.14 & 1.14 & 1.04 & 1.11 & 1.02 \\
\hline Rift Valley & 0.98 & 0.97 & 0.97 & 0.98 & 0.96 \\
\hline Western & 0.96 & 0.98 & 0.95 & 0.95 & 1 \\
\hline Nyanza & 0.99 & 0.99 & 0.99 & 0.99 & 1 \\
\hline North Eastern & 0.62 & 0.63 & 0.71 & 0.73 & 0.63 \\
\hline TOTAL & $\mathbf{0 . 9 9}$ & $\mathbf{1}$ & $\mathbf{0 . 9 8}$ & $\mathbf{1}$ & $\mathbf{0 . 9 4}$ \\
\hline
\end{tabular}


The challenge of pro-poor education was immense. In 2007, the results from the Kenya National Literacy Survey (KNALS 2007) showed that national illiteracy rates had risen to $38.5 \%$ of the adult population. This translated in to some $7.8 \mathrm{~m}$ Kenyan people being defined as illiterate.

Only $29.6 \%$ of the Kenya adult population has attained desired mastery literacy competency. About $29.9 \%$ of the youth aged $15-19$ years and $49 \%$ of adults aged $45-49$ years are illiterate. The survey reveals high regional and gender disparities in literacy achievements with Nairobi recording 87.1 percent and North Eastern province the lowest 8\% (MOE , 2008a:4)

A national task force on gender and education was established in 1995. But progress in this area was slow. It took till 2008 for MOE to introduce a national policy on gender and education (Republic of Kenya, 2007). The policy provided a framework for the planning and implementation of gender responsive education, as well as research and training. The general objective was to establish mechanisms to eliminate all gender disparities in education in relation to access, enrolment, retention, completion, performance, transition, quality and outcomes (Republic of Kenya, 2007:7)

With a policy in place the scene appeared set for a progressive period of gender development across the education system. However, there have been some serious setbacks. These include the violence which followed the 2008 national elections, which resulted in 1,300 deaths and over 350,000 people being displaced, predominantly in areas of the Rift Valley, Nyanza and Nairobi (Anderson and Lochery 2008; Cheeseman 2008; Githinji and Homlquist 2008; Githongo 2008 and Mueller 2008). Allegations of endemic and large-scale corruption have been made from a number of quarters (Wrong, 2009). A recent (2009) audit of parts of the KESSP carried out jointly by the UK and Kenyan National Audit offices found evidence of misuse of funds. This resulted in both the United Kingdom and the United States suspending aid to the Ministry of Education in early 2010. It is understood UK aid will now bechanneled to education via non government means in an effort to address ongoing poverty.

Kenya remains a deeply inequitable society. Sustained inter-generational poverty is linked to a host of complex structural and historical issues including land and property ownership, gender biased inheritance laws, low access to the labour market for women and a host of other intersecting elements. In 2002, it was estimated $56 \%$ of the Kenyan population (circa $17 \mathrm{~m}$ of 36 million) were living below the poverty line - and that this was projected to increase to $69.5 \%$ of the population by 2015 if current trends continue (Republic of Kenya 2007). 


\section{Researching policy addressing poverty, gender, schooling in Kenya and South Africa}

The recent histories of South Africa and Kenya are marked by inequalities and social division. In both countries governments have focused on education as one element in a pro-poor political and economic policy and comprehensive policy statements on gender and education have been developed. But the context for policy enactment has not been immensely difficult. In Kenya ongoing effects of the post 2007 election violence and the focus on corruption has edged gender and poverty off the national agenda. In South Africa, political struggles over the direction of the ANC, enmeshed gender and women's activists in discussions about whether the Polokwane resolutions entailed a step forward or backwards for gender equality concerns (Watson, 2009; Saul, 2010). The limits of the bureaucratic gender machinery and the fragility of its connection with civil society organisations (Gouws, 2006 ; Hassim, 2005) formed a significant backdrop to putting gender policy into practice. In Kenya the very marked gender hierarchies evident in land-ownership, participation in the labour market, political decision-making and higher education stand in contrast to South Africa. Here, while gender inequity is noted in politics, work, and social relations, the level of inequity in the distribution of opportunity is not quite as marked as in Kenya. But the extent of poverty and gender equality is just as grave, even if it takes different forms. Both countries share a challenge to address multiple inequalities. What work have they done?

From 2007-2010 a multi-country research team collected data for ten case studies of the implementation of policy on gender, education and poverty reduction in Kenya and South Africa. Qualitative methods have been used to explore how global and national policy agendas on gender and education are being negotiated in local settings. Methods include interviews, observations and document analysis in each country in the national Department/Ministry of Education, a provincial department, a school, a global NGO networking with NGOs in other countries, and a local NGO. The two schools in the study are state funded and each is located in a peri-urban area enrolling children from low income families who live in the neighbourhood. The local NGO in each country works with rural communities.

\section{Boundaries between poverty and gender in the provision of education}

The data indicate that it is difficult for government officials, teachers and NGO workers to make connections between questions of poverty and gender. In the absence of an idea of intersection understandings about enacting policy draw on frameworks provided by bureaucratic organisation. A 
gender and education policy text is an important framing of aspiration, but there have been challenges in developing a sense of ownership and engagement with the existing documents. Teachers and school committees who have had few opportunities to think about questions of gender, poverty and schooling reproduce stereotyped views about girls, boys and poor parents. The two NGOs in the study, which see themselves filling a gap in state provision for the poorest, are either disengaged from government action or unreflective about connections between gender hierarchies and poverty.

\section{Working in silos}

Many officials, when interviewed in the government departments, did not have a clear sense of connection or co-ordination in their work on gender, education and poverty and found questions on this difficult. One participant in the South African national Department of Education explained "I am not in the general socio-domain so you are asking a question that's not within my control". While this official went on in the interview to discuss gendered roles in the context of poverty, and the way in which additional burdens often fall on girls there was a clear perception connecting gender and poverty was not part of a specific remit.

Keeping gender issues under review in all areas of work was a challenge. An official in South Africa national Department recognised that

We work in silos, there is little opportunity to make those connections and also because... you are very much pushed to deliver on projects

Most Kenyan officials in the Ministry felt that questions about gender were not their remit, as a special desk for gender had been established:

You see the ministry of education has a gender desk that addresses the wider issues... the ministry has a gender desk and ... we're dealing on gender issues in education, manpower affirmative action...,

For those, whose work in the Department or Ministry was primarily focused on poverty reduction, poverty was seen as a priority issue, pushing gender lower further down the agenda. The assumption was that as poverty affected both boys and girls there was no need for poverty reduction programmes to consider gender. Officials in the South African Education Department were explicit about this: 
Like I say it (gender) is much more secondary to us because we deal much more with poverty and poverty is poverty whether you are male or female... we deal with hunger and hunger does not discriminate. For us gender doesn't come out as an issue (DoE p5).

At the moment it's looking at the classrooms, class size, putting toilets and water. And it's not just about whether it's a man - it's about whether we are supposed to provide education, we have that. So that's why I say it's more and more poverty alleviation. I think that's what would make life easier for many children to attend school irrespective of their gender ( DoE p7).

In Kenya there was an implicit assumption that talking about poverty and FPE did not entail thinking about gender. Gender neutral terms about families and households were used, with little focus on some of the gender dynamics of poverty:

Another issue I could also highlight is the fact that free primary education and free secondary education are part of this, because when families, households are able to put a lot of their earnings aside rather than in education. First, when education is subsidised, households can use the extra money in other ways. Two, parents who otherwise would not have been able to take their children to school are able to do so ( MoE p9).

One South Africa participant from the national department was concerned that a focus on gender would distract attention from the needs of the poorest:

You know the one risk you run with too much emphasis on gender issues, is generally speaking, issues like this would be taken more in more well resourced areas and what then happens is you get a lot of attention on women who are in well-to-do sectors of society and if that happens at the expense of the poor, then your anomalies, your asymmetries still remain.

Clearly for officials in the national Department/Ministry implementing the pro-poor education policies of both governments, one stream of work is focussing on poverty and one stream is focussing on gender. The gender issues facing schools serving the lowest quintiles have not been identified, and the gender inequalities associated with poverty understood either as a line, a net or fuel and how these might have a bearing on access to and attainment in school have not been considered beyond particular interventions associated with lifting fees or providing food. A considerable challenge to break down the silos exists. 


\section{Gender and education policy as text not practice}

In both countries, effort had gone into the development of policy documents on gender and education. In South Africa, a major review of gender and education issues had taken place eleven years before data collection began, and the Minister at the time of the main phase of data collection, had a history of concern with gender. A number of officials, employed at national and provincial level had been active in the women's movement. In Kenya the national gender policy was launched just before data collection began and an appointment of an official with this as a dedicated brief was made. Representatives from both countries have been active in international gatherings promoting the MDGs and EFA. However, despite the development of policy texts discussing many features of gender, participants in both countries and in all the case study sites were unfamiliar with discussions concerning many different facets of gender inequality. At school-level, we found that national gender policy documents had not been distributed. In addition there was very little knowledge of, or sense of involvement with, global mobilisation for gender equality in education. The head teacher at the school in South Africa when asked about his knowledge of the MDGs said:

I do heard about it, but I've never given my time to get an explanation about it because it's never touched...if you get something from far, not next to you, it's very hard.

This sense of the not being 'connected properly' to the MDG process was mirrored in his sense of being far away from the national gender and education policy process

I know that there is national policy talking about gender...I know about it ...But l've never learned about it...l've never had access to it.

$\mathrm{He}$, like the head teacher in Kenya, asked the research team to help get a copy of the national gender and education policy.

While the provincial gender officers in South Africa knew of the national gender concerns, they were sorely stretched to put these into effect, given the wide range of other tasks they performed and commented on the lack of a policy framework that could secure them resources and personnel (Karlsson, 2010 forthcoming). In Kenya there was little knowledge or priority given to the national gender policy at provincial level. The local NGOs working on girls' education projects with rural communities in both countries also did not use national discussion about gender and education as part of their framework. In South Africa, the local NGO had little connection with the work of the province. In Kenya, one local NGO worker interviewed more than a year after the national Gender and education policy had been launched when asked about the national policy said: 
We are just trying to put this in order. We are trying to see the policy, discuss it with other people so that we can roll it out.

It is evident that the policy texts, formulated by small insider groups at national level have not been widely disseminated or used to develop reflection on gender issues in local contexts. In the absence of any process of reflecting on national policy frameworks the nature of gender inequality is not understood in relation to the many features of inequalities associated with poverty, but rather in terms of static notions of equal numbers or amounts. Thus there was a widespread view of education poverty as a line and the major work of the school was to ensure that it could be crossed by girls and boys in equal numbers. Many held views that schools and education policy should be gender neutral, with the focus on obtaining "balance" in terms of numbers of boys and girls in school, and a concern to ensure that neither sex can been seen to be favoured over the other.

One Kenyan participant from the national ministry explained ...in our gender policy we have been keen to incorporate both boys and girls in school we make it plain. Our agenda is to have both boys and girls in school. Free primary education is about boys and girls in school and that's why we tend to receive a good response of people because we don't want to make it a gender issue

Similarly in South Africa, a number of national ministry participants saw the broader policy framework on race and gender equality, generally interpreted as a concern with equal numbers, providing an adequate framework. One official explained:

gender parity is as you know in the policy framework. What we have tended to do is, you know, when for example if we're doing selection of teachers for programmes, we do - the general representivity comes up all the time. To that extent it is addressed.

At school level similar ideas of balance and equal numbers were evident. In Kenya, the headteacher of the school explained

there is balance. If the head boy is a boy then the assistant is a girl. If the game captain is a boy, then we have a girl assisting, so we balance

In a later interview he said

I think that we should balance and not only concentrate on the girl child. People are uplifting women and forgetting about the men. I think that is why it is called gender equality because we need both of them. 
Similarly in South Africa, the head teacher interpreted gender - and the gender policy - as being about quotas - or numbers of men and women in different positions:

you know, actually, we do hear about the gender policy. It's like a quota in sport. Let's take for instance in cricket or rugby when people are saying 'no let's do this, let's do this' even though there is a policy which says there must be this and this. [For example] people who are participating in this sport must be in this number. Same applies to this in our school.

The idea that gender issues concerned equal numbers is thus widespread. The notion of gender balance thus operates to close off an understanding of gender as relational and the ways in which inequalities might intersect. One outcome of this was that school communities had developed particularly stereotyped ways of thinking about girls, boys and poor communities.

People in outline: Stereotyping girls, boys and the poor

In both countries, we found girls present in school in adequate numbers, but the schools were not addressing gender stereotypes or conventions or reflecting on how relations linked with the experience of poverty might cement this. The researchers at the Kenyan school noted that the girls were responsible for mopping classroom floors whilst the boys fetch water. The head teacher said that this was because:

the girls prefer to clean and they say "Mwalimu, let us clean so that we can go home early because when the boys clean they are not as fast as we are

When asked about girls' roles and responsibilities within the home that may hinder their performance in school the Kenyan headmaster explained "culturally we tend to see and train a girl at an early stage in those (home) responsibilities more than the boys. They even come without noticing."

Similarly in the South African school, it was clear that girls and boys were expected to carry out different duties, which was explained by the head teacher as something that happens "naturally":

You know in our culture (I don't know if it's a black culture or what) where you find in olden days where you find a man go to the veld to look after the fold and then the female person used to collect the wood in order to make a fire at home. Same applies to here. Even we don't apply that method but it happens naturally.

there is a difference between a boy and a girl when it comes to cleaning. It's like cooking. I can cook. I cook. But only to find a lady can cook better than me because I'm not trained to do that. But naturally a female person can do better things than me when it comes to cooking and cleaning.

The replication of taken-for granted gender divisions in cleaning and cooking, and the head-teachers' assumptions about the traditional cultures that kept this in place suggest that teachers who work 
with the poorest children have had few opportunities to think about and reflect on the consequences of entrenched sexual division of labour within and beyond families and what this might mean for engaging with gender inequalities associated with poverty or other forms of social division.

There is a good representation of women among the teachers at the school (although both headteachers are men). But women are not prominent in decision-making bodies. In both countries women make up a minority of those on the school governing board. In the South African school the school governing body comprises 6 men and 2 women, plus the (male) principal who serves as exofficio as the manager of the school. In the Kenyan school the membership comprises eleven men and two women. Two places are open, reserved for women to represent two classes but at the time of the data collection they were still to take their positions. These governing bodies were largely concerned with financial and administrative issues. Although they participated in lively discussions about preliminary findings from the study and the need to look deeper into questions of gender inequality, there are clearly few forums for this.

The ways in which a focus on gender neutrality created a boundary beyond which it was difficult to engage in more complex discussions about gender was mirrored in the ways teachers and school communities commented on poverty. In both countries teachers at the schools were keen to distance themselves socially and discursively from poor parents, whom they often blamed for the conditions they found themselves in and their children's weak performance at school (Unterhalter et al, 2009). The parents and their poverty were presented in stereotyped form with little understanding of relationships and experience. In the view of the Kenyan SGB, the parents made no contribution to the school:

The SGB has long had parents who do not support the school in its running in that they do not positively guide their children given that the school is in a slum.

Single mothers were singled out for particular criticism, with a strong discourse around notions of "morality" or respectability:

some of the mothers are single and they engage themselves in prostitution or commercial sex.

In South Africa too the SGB saw poor parents as the obstacle to children crossing the line into school:

No one motivates such children to attend school so they go and start working then the parents become dependent on them for food and income. 
Condemnation of parents focussed particularly on their neglect which resulted in girls getting pregnant. Some participants described girls as 'immoral', 'doing wrong' and 'heated by adolescence". In South Africa many negative comments were made about girls who it was said became pregnant just to claim the child support grant. Receiving the grant, it was claimed, disrupted established family patterns of seniority because girls had more money than they deserved, and were believed to be using the grant money to have their hair plaited, buy air time for their phones, and go out with friends rather than look after their children. While these condemnations stand in contrast to interviews with women and girls who came from households where the grant was received and where there was evidence that the grant had given women the capacity to buy food and provide for households, the level of antipathy towards them by teachers and school communities indicates enormous challenges in addressing gender and poverty.

\section{Conclusion}

The data indicate that at the level of policy formulation and enactment poverty, gender and schooling are understood as connected only in terms of particular notions of lines, that is being in and out of school, or having 'gender balance'. One consequence of drawing these lines is that forms of gender inequality and denigration of the poor are reproduced in schools. Government officials, teachers, SGBs and NGOs do not have a language or a framework for policy and practice in which they can think about the connections between gender and poverty. The idea of intersecting inequalities and that poverty and gender might comprise simultaneously lines, nets and fuel suggests a more complex approach. While translating complex ideas into practice is immensely difficult the development of a working language and the formulation and application of analytical frames are important precursory steps in the process of achieving a deeper and more nuanced understanding of the working and implications of intersecting processes. Walking this route offers a possibility to understand how to give the poorest girls a fair chance to succeed. Gender equity cannot be indifferent to the many processes that undermine it and a first step is to understand what those processes are. 


\section{REFERENCES}

African National Congress. 1994. The reconstruction and development programme: a policy framework. Johannesburg: African National Congress.

African National Congress. 2007. ANC 52nd National Conference 2007 resolutions. http://www.anc.org.za/show.php?doc=ancdocs/history/conf/conference52/resolutions.html (accessed 3 May 2010).

Aikman, S. (1999). Schooling and development: Eroding amazon women's knowledge and diversity. London: Zed Books.

Aikman, S. (2002). Women's oral knowledge and the poverty of formal education in the se peruvian amazon. Gender \& Development, 10(3), 41 - 50.

Ames, P. (2005). When access is not enough: educational exclusion of rural girls in Peru. In S. Aikman \& E. Unterhalter (Eds.), Beyond Access: Transforming Policy and Practice for Gender Equality in Education. Oxford: Oxfam.

Anderson D and Lochery E (2008) Violence and the Exodus in Keny'a rift Valley, 2008: Predictable and Preventable? in Journal of Eastern African Studies, Vol., 2, No., 2, pp 328-343

Anthias, F. and N. Yuval-Davis (1983) 'Contextualizing Feminism: Gender, Ethnic and Class Divisions', Feminist Review 15: 62-75.

Arends-Kuenning, M., \& Amin, S. (2004). School incentive programs and children's activities: The case of Bangladesh. Comparative Education Review, 48(3), 295-317.

Bandyopadhyay, M. and Subrahmanian, R. (2008) Gender Equity in Education: A

Review of Trends and Factors. CREATE Pathways to Access Research

Monograph No. 18. New Delhi/Falmer: CREATE and NUEPA.

Bhana, D., \& Epstein, D. (2007). "I don't want to catch it". Boys, girls and sexualities in an hiv/aids environment. Gender and Education, 19(1), 109 - 125.

Chant, S. (2007). Gender, generation and poverty: Exploring the 'feminisation of poverty' in Africa, Asia and Latin America. Cheltenham: Edward Elgar.

Chant, S. (2008). Beyond incomes: A new take on the 'Feminisation of Poverty'. Poverty in Focus, 13, 26-27.

Cheeseman N (2008) The Kenyan Elections of 2007: An Introduction in Journal of Eastern African Studies, Vol., 2, No., 2, pp 166-184 
Crenshaw, K. (1989) Demarginalizing the intersection of race and sex: A Black feminist critique of antidiscrimination doctrine, feminist theory and antiracist politics. University of Chicago Legal Forum 1989 , pp. 139-167.

Department of Education. 2007. Measures on the Prevention and Management of Learner Pregnancies. Pretoria: Department of Education.

Department of Education. 2009. Trends in education macro indicators: Summary report. Pretoria: Department of Education.

Department for International Development (DFID (1999) Project Submission - Strengthening of Primary Education Project Phase III (SPRED III) Nairobi-London Department for International Development.

Deprez, L. and Butler, S. (2007) Higher Education and Well Being in E. Unterhalter \& M. Walker (Eds.), Sen's capability approach and social justice in education. London: Palgrave.

Dieltiens, V., Letsatsi, S., Unterhalter, E., \& North, A. (2009). Gender blind, gender neutral: Bureaucratic screens on gender equity. Perspectives in Education special issue on "Diversity in Education".

Emmett, T. (2006). Disability, poverty, gender and race. In Disability and social change: A South African agenda. Edited by B. Watermeyer, L. Swartz, T.

Lorenzo, M. Schneider and M. Priestley. HSRC Press: Cape Town. $207-233$.

Filmer, D. 2008: "Inequalities in Education: Effects of Gender, Poverty, Orphanhood, and Disability." In Girls Education in the 21st Century: Gender Equity, Empowerment, and Economic Growth, ed. M. Tembon and L. Fort (Washington, DC: World Bank), 95-113.

Fiszbein, A. and N. Schady (2009). Conditional cash transfers: Reducing present and future poverty. Washington, World Bank.

Fleisch, B. and Shindler (2009). Patterns and Prevalence of School Access,

Transitions and Equity in South Africa: Secondary Analyses of BT20 Large-Scale Data Sources CREATE PATHWAYS TO ACCESS Research Monograph No 27 Retrieved from http://www.research4development.info/PDF/Outputs/ImpAccess_RPC/PTA27.pdf

Giri, B. (2009). The bonded labour system in nepal: Perspectives of haliya and kamaiya child workers. Journal of Asian and African Studies, 44(6), 599-623.

Githinji M W and Holmquist F (2008) Kenya's Hopes and Impediments: The Anatomy of a Crisis of Exclusion in Journal of Eastern African Studies, Vol., 2, No., 2, pp 344-358

Githongo J (2008) Kenya - Riding the Tiger in Journal of Eastern African Studies, Vol., 2, No., 2, pp 359-367

Gouws, A (2006) "The State of the National Gender Machinery: Structural Politics and Personalised Politics" in State of the Nation 2005-2006, Human Science Research Council, Cape Town. 
Govender, P. 2009. In the name of culture. Mail \& Guardian, 20-26 March, 3. Democracy 2009: Gender section.

Greany, K. (2010) Posting to week one of the Engndering Empowerment: Education and Equality (E4) e-conference. Retrieved from http://www.e4conference.org/e4e/w1

Green, D. 2008. From Poverty to Power: How active citizens and effective states can change the world. Oxford: Oxfam International.

Hassim, S. (2005). Voices, hierarchies and spaces: Reconfiguring the women's movement in democratic south africa. Politikon: South African Journal of Political Studies, 32(2), 175 - 193.

hooks, b. (1981) Ain't I a Woman?: Black Women and Feminism. Boston, MA: South End Press.

hooks, b. (1992) Black Looks: Race and Representation. Boston, MA: South End Press.

hooks, b. (1994) Outlaw Culture: Resisting Representations. New York: Routledge.

Hsin, A. (2007). Children's time use: Labor divisions and schooling in indonesia. Journal of Marriage and Family, 69(5), 1297-1306.

Huisman, J., \& Smits, J. (2009). Effects of household- and district-level factors on primary school enrollment in 30 developing countries. World Development, 37(1), 179-193.

Kabeer, N. (1996). Agency, Well-being \& Inequality: Reflections on the Gender Dimensions of Poverty. IDS Bulletin, 27(1), 11-21.

Kabeer, N. (2007). Marriage, motherhood and masculinity in the global economy: Reconfigurations of personal and economic life. Brighton: Institute of Development Studies.

Kamwendo, M. (2010). Constructions of malawian boys and girls on gender and achievement. Gender and Education.

Karlsson, J. (2009) Understandings about the interrelationship of gender inequality, poverty and education, and gender-based strategies to reduce poverty: Some findings from two case studies in the South African education sector, Agenda, 81: 71-79.

Karlsson, J. (2010 forthcoming) Gender mainstreaming in a South African provincial education department: A transformative shift or technical fix for oppressive gender relations? Compare 40(4)

Kenya Ministry of Education (MoE) (2008) Kenya Education Sector Support Programmer (KESSP) Joint Annual Budget Review (JABR) Aide Memiore - April 2-4 2008 Nairobi, Ministry of Education.

Kenya MOE (2008a) Vision 2030 Medium term plan Education and training Nairobi MOE, Republic of Kenya

Kumar, R., S. Kumar, \& Anurag (2007) Regional Dimension of Disparities in Slum Literacy in India Research and Practice in Social Sciences Vol. 2, No. 2 (Feb. 2007) 103-123

Leach, F., \& Humphreys, S. (2007). Gender violence in schools: Taking the "Girls-as-victims" Discourse forward. Gender \& Development, 15(1), 51 - 65. 
Leggett, I. (2005) Learning to improve education policy for pastoralists in Kenya In S. Aikman \& E. Unterhalter (Eds.), Beyond Access: Transforming Policy and Practice for Gender Equality in Education. Oxford: Oxfam.

Lesorogol, C. K. (2009). Asset building through community participation: Restocking pastoralists following drought in northern kenya. Social Work in Public Health, 24(1), 178 - 186.

Lewin, K. (2009). Access to education in sub-saharan africa: Patterns, problems and possibilities. Comparative Education, 45, 151-174.

Lewis, M. A., \& Lockheed, M. (2006). Inexcusable absence: Why 60 million girls still aren't in school and what to do about it Washington DC: Center for Global Development.

Lister, R. (2004) Poverty. Cambridge: Polity .

Lloyd, C. B., Grant, M., \& Ritchie, A. (2008). Gender differences in time use among adolescents in developing countries: Implications of rising school enrollment rates. Journal of Research on Adolescence, 18(1), 99-120.

Lund, F. 2008. Changing social policy: the child support grant in South Africa. Cape Town: HSRC Press. Marais, H. 1998. South Africa: Limits to change: The political economy of transformation. Rondebosch: UCT Press.

Maslak, M. A. (2003) Daughters of the Tharu: gender, ethnicity, religion and the education of nepali girls Falmer , New York: Routledge

Ministry in the Office of the President. 1994. White paper on reconstruction and development. Cape Town: Parliament of the Republic of South Africa.

Ministry of Education (2009) Education Statistics 2003-2007, Nairobi, Ministry of Education

Molyneux, M. (2006). "Mothers at the Service of the New Poverty Agenda: Progresa/Oportunidades, Mexico's Conditional Transfer Programme." Social Policy \& Administration 40(4): 425-449.

Morley, L., \& Lugg, R. Mapping meritocracy: Intersecting gender, poverty and higher educational opportunity structures. High Educ Policy, 22(1), 37-60.

Morrell, R., Epstein, D., Unterhalter, E., Bhana, D., \& Moletsane, R. (2009). Towards gender equality: South african schools during the hiv and aids epidemic. KwaZulu-Natal: University of KwaZulu-Natal Press.

Motala, E. and J. Pampallis. 2007. Implementing education policies in the post-apartheid state: debates on the dilemmas between policy and practice. In Dilemmas of implementing education reforms: explorations from South Africa and Sweden, eds. C. Odora Hoppers, B. Gustavsson, U. Lundgren, E. Motala and J. Pampallis, 369-90. Uppsala: Uppsala University.

Mueller S D (2008) The Political Economy of Kenya's Crisis in Journal of Eastern African Studies, Vol., 2, No., 2, pp 185-210

Murunga G R and Nsong'o S W (2007) (Eds.) Kenya: The struggle for democracy London Zed books/Dakar CODESRIA 
Murunga G R (forthcoming 2010) Kenya - Democracy on trial, London Zed

Mugisha, F. (2006). School enrollment among urban non-slum, slum and rural children in kenya: Is the urban advantage eroding? International Journal of Educational Development, 26(5), 471-482.

Nnaemeka, O. (2004). Nego - feminism: Theorizing, practicing, and pruning africa's way. Signs: Journal of Women in Culture and Society, 29(2), 357-385.

North, A. (2010 forthcoming) MDG 3 and the negotiation of gender in international education organisations Compare 40(4)

Nyembezi, N. and M. Makhawula. 2009. The trouble with teenagers. The Mercury, 2 March, 6.

Onsongo, J. and Makinda, H. (2009) Do poverty reduction interventions address gender issues in education? Reflections from research in the departments of education in a Kenya province and district paper presented at the 10th UKFIET International Conference on Education and Development. Oxford, 15 - 17 September 2009

Oommen, M. (2005). 'crossing boundaries and stepping out of purdah in india'. In S. S. Aikman \& E. Unterhalter (Eds.), Beyond access. Transforming policy and practice for gender equality in education Oxford: Oxfam.

Page, E. (2005). 'Gender and the construction of identities in indian elementary education'. Unpublished unpublished PhD Thesis, Institute of Education, University of London.

Parkes, J. (2007). The multiple meanings of violence: Children's talk about life in a south african neighbourhood. Childhood, 14(4), 401-414.

Phoenix, A. and Pattynama P. (2006) 'Editorial: Intersectionality', European Journal of Women's Studies 13(3): 187-92

Pressley, D. (2009)' South Africa has the widest gap between rich and poor' Business Report September 28 http://www.busrep.co.za/index.php?fArticleld=5181018

Ramachandran, V. (2001) Community Participation in Primary Education: Innovations in Rajasthan Economic and Political Weekly, Vol. 36, No. 25 (Jun. 23-29, 2001), pp. 2244-2250

Raynor, J. (2007) Schooling girls: An inter-generational study of women's burdens in rural Bangladesh in Fennell, S., \& Arnot, M. (Eds.). (2007). Gender education and equality in a global context: Conceptual frameworks and policy perspectives. London: Routledge.

Republic of Kenya (2004) Investment Programme for the Economic Recovery Strategy for Wealth and Employment Creation (PRSP), Nairobi : Government of Kenya

Republic of Kenya (2007) The gender and education policy. Nairobi: Government of Kenya

Republic of Kenya (2009) Kenya AIDS Indicator Survey 2007, Nairobi

Republic of South Africa. 1996a. Constitution of the Republic of South Africa Act, No 108. Pretoria: President's Office.

Republic of South Africa. 1996b. South African Schools Act. Pretoria: President's Office. 
Saul, J. S. (2010). Race, class, gender and voice: Four terrains of liberation. Review of African Political Economy, 37(123), 61 - 69.

Savides, M. 2009. Social grants at R13bn 'not enough'. The Mercury, 12 Feb, 6.

Seekings, J. and N. Nattrass. 2006. Class, race, and inequality in South Africa. Scotsville: University of KwaZulu-Natal Press.

Sen, M., S. Rastogi and R. Vanneman. 2006. Disempowered by whom? Gender vs. generation in family decision making. Paper presented at the Annual Meeting of the Population Association of America, Los Angeles, March.

Shin, H. (2008). A new insight into urban poverty: The culture of capability poverty amongst korean immigrant women in los angeles. Urban Studies, 45(4), 871-896.

Skeggs, B. (1997) Formations of Class and Gender: Becoming Respectable. London: SAGE.

Society for International Development (2004) Pulling Apart: Facts and Figures on Inequality in Kenya Nairobi, Society for International Development

Swatz, S. and Bhana, A. (2009) Teenage Tata Voices of young fathers in South Africa. Cape Town: HRSC Press

Thomson A et al (2009) Mid-Term evaluation of the EFA Fast Track Initiative Country Case Study: Kenya, Mokoro /Cambridge Education and Oxford Policy Management - for FTI Washington

UNESCO (2010) Global Monitoring Repor 2010: Reaching the Marginalised Paris: UNESCO/Oxford University Press

Unterhalter, E., 2010 Partnership, participation and power for gender equality in education. Situation analysis prepared for the UNGEI E4 conference, New York: UNGEI. online at http://www.e4conference.org/wp-content/uploads/2010/03/SituationAnalysis EN.pdf

Unterhalter, E., 2009 'Gender and poverty reduction: The challenge of intersection' Agenda 81, 1424

Unterhalter, E. (2007). Gender, schooling and global social justice. London: Routledge.

Unterhalter, E., Dieltiens, V., Onsongo, J., North, A., \& Makinda, H. (2009). Mainstreaming, sidestreaming and engaging global agendas: The challenge of institutionalising gender equality in education in kenya and south africa, working paper 2 , gender, education and global poverty reduction initiatives.

Van Der Westhuizen, C. 2009. Restructuring gender machinery: Government departments must communicate publicly on the important issue of gender. The Mercury, 31 August, 7.

Watson, J. (2009) Polokwane - Taking Women One Step Forward or Two Steps Back? Unpublished paper retrieved from http://www.5050.org.za/downloads/2009071420090713151731_WGWATSONJ0907CT.pdf 
World Bank (2003) Project Appraisal Document For the Free Primary Education Support Project Nairobi, World Bank, Africa Region

Wrong M (2009) Its our Turn to Eat - The story of a Kenyan Whistle Blower. London: Fourth Estate Yates C, Foster D and Barasa L (2010 forthcoming) Education reform in Kenya: Institutionalising the provision of instructional materials and in-service teacher education for quality primary educationResearch Report 2 - Nairobi, MOE-DFID 